\title{
REKAYASA PERANGKAT LUNAK PERANCANGAN \\ DAN PEMBUATAN AUGMENTED REALITY \\ SHOOTING GAME
}

\author{
Clara Isabella Menayang1), \\ Jenisa Felisa ${ }^{2)}$
}

STMIK LIKMI Bandung

J1. Ir. H. Juanda no 96 Bandung 40132

E-mail : clara.mw2@gmail.com¹), jenisafelisa@gmail.com²)

\begin{abstract}
ABSTRAK
Penelitian bertujuan untuk merancang sebuahshooting game dengan Augmented Reality yangdiimplementasikan pada smartphone dengan sistem operasi android. Proses perancangan gamemenggunakan game engine Unity3D. Unity3D didukung oleh berbagai Software Development Kit (SDK) yang dibutuhkan untuk membuat game augmented reality seperti salah satu contohnya Vuforia.Dalam penelitian disimpulkanbahwa hasil dari tugas akhir ini adalahperangkat lunak game augmented reality berbasis android menggunakan game engine Unity $3 D$ dapat dibuat dan berjalan dengan baik dengan adanya Vuforia sebagai SDK yang berfungsi untuk mengaktifkan kamera yang memiliki fitur melacak suatu target. Untuk melacak target dapat dilakukan secara markerless, dimana tidak butuh sebuah marker.
\end{abstract}

Kata kunci : Shooting Game, Augmented Reality, Unity3D, SDK Vuforia, Markerless.

\section{PENDAHULUAN}

Augmented Reality (AR) adalah penggabungan benda-benda nyata dan maya sehingga kita bisa melihat benda tiga dimensi (3D) muncul pada lingkungan nyata dalam AR. AR pertama kali dikembangkan di Sutherland pada tahun 1965, para peneliti memanfaatkan teknologi ini sebagai salah satu cara baru untuk meningkatkan produktifitas, efektifitas dan efisiensi serta sebagai media entertainment. Sampai saat ini AR telah banyak digunakan di dunia hiburan, pelatihan militer, medis, desain rekayasa, robotik dan telerobotik, manufaktur, pendidikan, dan lain-lain.

Beberapa tahun terakhir kemampuan perangkat mobile telah mengalami perkembangan yang cukup pesat dengan kehadiran beberapa sistem operasi baru yaitu Android, IOS, dan Windows Phone, dan tidak hanya software yang terus diperbaharui tetapi hardware pada smartphone pun selalu diperbaharui. Perangkat mobile pada saat ini memiliki kamera yang beresolusi tinggi dan didukung dengan prosesor yang cepat dengan memori yang besar. Dengan adanya smartphone yang mempunyai spesifikasi tinggi, memungkinkan pengimplementasian AR pada perangkat mobile yang lebih maksimal karena dapat memproses data lebih banyak dan lebih cepat.

Ada berbagai tipe game pada smartphone, salah satunya game dengan tipe shooting game seperti yang akan dibuat sebagai tugas akhir berikut, shooting game dimainkan dengan cara menembak target (hantu) yang bergerak. Pemain akan bermain sebagai seorang pemburu yang menembak target yang terbang melintas pada layar smartphone. Setiap tembakan yang tepat mengenai target, maka pemain akan mendapatkan poin. Game ini akan dibuat menggunakan game engine Unity. 


\section{STUDI LITERATUR}

\subsection{Augmented Reality}

Menurut Greg Kipper dan Joseph Rampolla (Kipper, 2012 : 1), Augmented Reality adalah suatu sistem yang bertujuan untuk mengembangkan teknologi yang memperbolehkan penggabungan secara real-time terhadap digital content yang dibuat oleh komputer dengan dunia nyata. Sehingga Augmented Reality memungkinkan pengguna melihat dunia nyata dimana objek virtual dua dimensi maupun tiga dimensi diproyeksikan ke dalam dunia nyata.

Menurut Alan. B. Craig (Craig, 2013 : 1), Augmented Reality itu sendiri adalah ide yang berhubungan antara manusia dengan komputer dan sebaliknya antara komputer dengan manusia, yang tentunya dalam hal untuk mengimplementasikan Augmented Reality ini membutuhkan teknologi yang terkini.

Augemented Reality sebagai sistem yang memiliki karakteristik sebagai berikut :

a. Menggabungkan lingkungan nyata dan virtual

b. Berjalan secara interaktif dalam waktu nyata.

c. Berintegrasi dalam tiga dimensi (3D)

Dalam buku Paul. A. Fishwick (Fishwick, 2008:123) menyebutkan bahwa pada tahun 1994 Paul Migran dan Fumio Kishino mengenalkan Mixed Reality dapat dilihat pada Gambar 2.3. Paul Migran dan Furnio Kishino mendeskripsikan bahwa terdapat celah yang menjadi pemisah antara lingkungan nyata dan lingkingan virtual. Diantara kedua lingkungan tersebut terdapat dua bagan yang menjadi jembatan yang memiliki kecenderungan yang berbeda. Dua bagan tersebut adalah Augmented Reality dan Augmented virtuality. Dapat dilihat dari gambar bahwa posisi kedua bagan tersebut berbeda, untuk Augmentedreality lebih dekat dengan lingkungan nyata dan Augmented virtuality lebih dekat dengan lingkungan virtual.

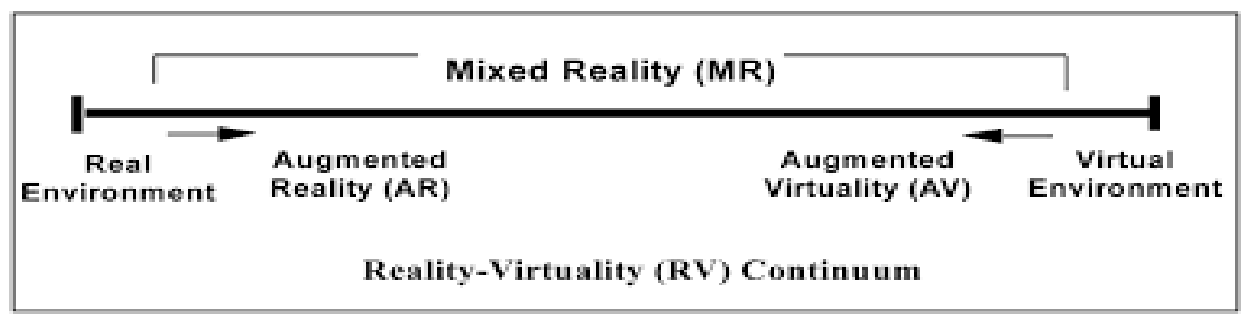

Gambar 1Mixed Reality

(Sumber : Milgram dan Kishino, 1994 : 283)

Untuk sisi paling kiri adalah lingkungan nyata dimana maksud dari lingkungan nyata adalah dimana terdapat benda-benda nyata, sedangkan untuk sisi paling kanan adalah lingkungan maya dimana terdapat benda-benda maya atau tidak nyata seperti lingkungan yang terdapat pada animasi 3D maupun 2D. Pada bagian Augmented Reality lingkungan bersifat nyata dan benda bersifat maya. Pada Augmented Virtuality kebalikannya , dimana lingkungan bersifata maya dan benda bersifat nyata. Oleh karena itu pengelompokan AR dan AV seringkali disebut sebagai Mixed Reality.

Dalam pembuatan AR beberapa komponen penting yang diperlukan dalam pembuatan dan pengembangan aplikasi AR adalah sebagai berikut :

1. Komputer : berfungsi sebagai perangkat yang digunakan untuk membuat sebuah aplikasi atau yang memproses semua yang akan terjadi pada aplikasi. Kemudian hasil 
yang telah dibuat / diproses melalui komputer akan ditampilkan di layar monitor atau layar ponsel.

2. Marker:berfungsi sebagai media gambar yang nantinya akan digunakan untuk proses tracking. Dimana sistem akan mengenali marker tersebut lalu akan menciptakan virtual objek 3D.

3. Kamera : berfungsi untuk memproses image yang ditangkap oleh kamera. Apabila kamera menangkap image yang mengandung marker, maka aplikasi yang ada di perangkat mobile akan mengenali marker. Lalu perangkat mobile akan menampilkan objek di atas marker tersebut.

Beberapa metode yang digunakan pada Augmented Reality diantaranya adalah Marker Base TrackingdanMarkerles Augmented Reality

\subsection{Markerless}

Menurut Mario Vento (Vento, 2009 : 24) salah satu metode Augmented Reality yang saat ini sedang berkembang adalah metode Markerless Augmented Reality, dengan metode ini pengguna tidak perlu lagi menggunakan sebuah marker untuk menampilkan elemen-elemen digital. Seperti saat ini dikembangkan oleh perusahaan Augmented Reality terbesar di dunia Total Immersion dan Qualcomm, mereka telah membuat berbagai macam teknik Markerless tracking sebagai teknologi andalan mereka seperti :

1. Face Tracking

Dengan menggunakan algoritma yang mereka kembangkan, komputer dapat mengenali wajah manusia secara umu dengan cara mengenali posisi mata, hidung, dan mulut manusia, kemudian akan mengabaikan objek-objek lain di sekitarnya seperti pohon, rumah, dan benda-benda lainnya.

2. Motion Tracking

Pada teknik ini komputer dapat menangkap gerakan, Motion tracking telah mulai digunakan secara ekstensif untuk memproduksi film-film yang mencoba mensimulasikan gerakan.

3. GPS Tracking

GPS tracking adalah teknik yang memanfaatkan fitur GPS dan kompas yang ada di dalam perangkat mobile. Aplikasiakan mengambil data dari GPS dan kompas kemudian akan menampilkan dalam bentuk arah yang kita inginkan secara real time.

4. Device Tracking

Teknik ini memanfaatkan rotasi yang ada di perangkat mobile, maksud dari rotasi ini adalah objek berada di titik tertentu dan ketika perangkat mobile kita putar di sekitar lingkungan nyata, objek itu akan berada pada posisi yang di tetapkan.

\subsection{Vuforia}

Menurut Mario Fernando (Fernando, 2013 : 6) Vuforia adalah Augmented Reality Software Development Kit (SDK) yang digunakan pada perangkat mobile untuk pembuatan aplikasi Augmented Reality. Software development Kit ini menggunakan teknolgi computer vision untuk mengenali dan melacak gambar target dan objek 3D yang sederhana secara real time. Kemampuan ini memungkinkan para developer untuk membuat posisi dan orientasi objek virtual seperti model 3D dan media-media lainnya yang berkaitan dengan dunia nyata dapat dilihat melalui kamera dari perangkat mobile. Objek virtual tersebut selanjutnya melacak posisi orientasi dan gambar secara real time sehingga penggna dalam melihat objek tersebut melalui layar kamera perangkat mobile sehingga seakan virtual objek tersebut adalah bagian dari dunia nyata.

Vuforia SDK menggunakan beberapa tipe target, 2D dan 3D, termasuk pengaturan untuk target yang jumlahnya lebih dari satu (multi target), seperti target berbentuk silinder 
untuk mendeteksi gambar yang berada pada permukaan silinder.Berikut ini beberapa kelebihan yang dimiliki vuforia SDK :

1. Mendeteksi dengan cepat target local dengan kapasitas melacak lima target secara simultan

2. Pendeteksian dalam keadaan kurang cahaya dan bahkan ketika target tertutup sebagian

3. Kapasitas pelacakan yang tinggi yang membuat aplikasi terus melacak target dan membantu dari suatu objek yang atau bahkan ketika target tidak lagi terlihat pada kamera.

Vuforia menawarkan banyak fitur $A R$ yang dapat dikombinasikan dalam pembuatan aplikasi antara lain :

1. Image target:Fitur yang menjadikan gambar sebagai target marker untuk menampilkan objek maya pada saat targer marker dikenali oleh aplikasi.

2. Cloud Recognition : Fitur yang akan melakukan scanning target untuk menampilkan objek maya, dimana data dari target marker-nya diambil dari cloud.

3. User defined target :Fitur yang memperbolehkan pengguna mendefinisikan targetnya sendiri sesuai keinginan pengguna untuk menampilkan dimana objek mayanya akan ditampilkan.

4. Virtual Button : Fitur yang menjadikan objek pada dunia nyata sebagai tombol dengan pendefinisian pada marker dengan bentuk persegi

5. Multi target : Fitur yang dapat melakukan scanning lebih dari satu target untuk menampilkan objek maya

6. Video playback : Fitur yang dapat menjalankan video ketika suatu marker terdeteksi oleh kamera.

7. Rotational Device : Fitur ini memungkinkan para developer menciptakan aplikasi yang dapat melacak rotasi dari posisi perangkat itu berada.

Dengan banyaknya fitur, vuforia menjadi salah satu extension yang banyak digunakan dalam pembuatan sebuah aplikasi Augmented Reality. Vuforia juga memiliki dokumentasi yang cukup lengkap serta dukungan dari forum yang aktif, sehingga memudahkan bagi para developer untuk mencari suatu informasi atau tutorial penggunaannya.

\section{ANALISIS DAN PERANCANGAN PERANGKAT LUNAK}

\subsection{Gambaran Umum Perangkat Lunak}

Perangkat lunak game "Ghost Hunter" adalah perangkat lunak yang dibuat untuk bertujuan sebagai media hiburan bagi player yang ingin memainkannya. Game "Ghost Hunter" adalah gamefirst person shooter dengan konsep menembaki objek - objek yang berada di sekitar lingkungan nyata yang berbentuk hantu.

Aplikasi ini dapat dimainkan menggunakan perangkat smartphone berbasis android yang menggunakan layar sentuh. Aplikasi "Ghost Hunter" ini juga menggunakan perangkat kamera pada smartphone itu sendiri sehingga kualitas dan resolusi gambar pada game tersebut tergantung oleh kamera pada smartphone yang dipakai.

Pada game "Ghost Hunter" terdapat beberapa fitur yaitu dapat melihat urutan High Score pada menu High Score dengan cara menekan button High Score pada tampilan menu utama. Selanjutnya pemain dapat melihat tutorial cara memainkan game dengan cara menekan menu about pada menu utama. Pemain juga bisa mengganti senjata pada saat game play dengan cara menekan button ganti senjata. 


\subsection{Spesifikasi Kebutuhan Perangkat Lunak}

\subsubsection{Analisa Kebutuhan Fungsional}

Game yang akan dibangun harus memiliki fitur seperti :
a. Dapat melihat menu score
b. Dapat melihat menu about
c. Dapat mengganti senjata
d. Dapat menempatkan posisi objek hantu secara acak,
e. Dapat dimainkan pada sistem operasi Android
f. Dapat mengakses kamera perangkat mobile

\subsubsection{Analisis Kebutuhkan non Fungsional}

Kebutuhan non fungsional yang dibutuhkan adalah sebagai berikut :

a. Smartphone dengan sistem operasi Android

b. Minimum Sistem operasi Nougat (7.0)

c. RAM 2GB

d. Minimum storage adalah $1 \mathrm{~GB}$

e. Kamera 3MP

\subsection{Use Case Diagram} gambar 2.

Diagram use case program aplikasi enkripsi dekripsi file data dapat dilihat pada

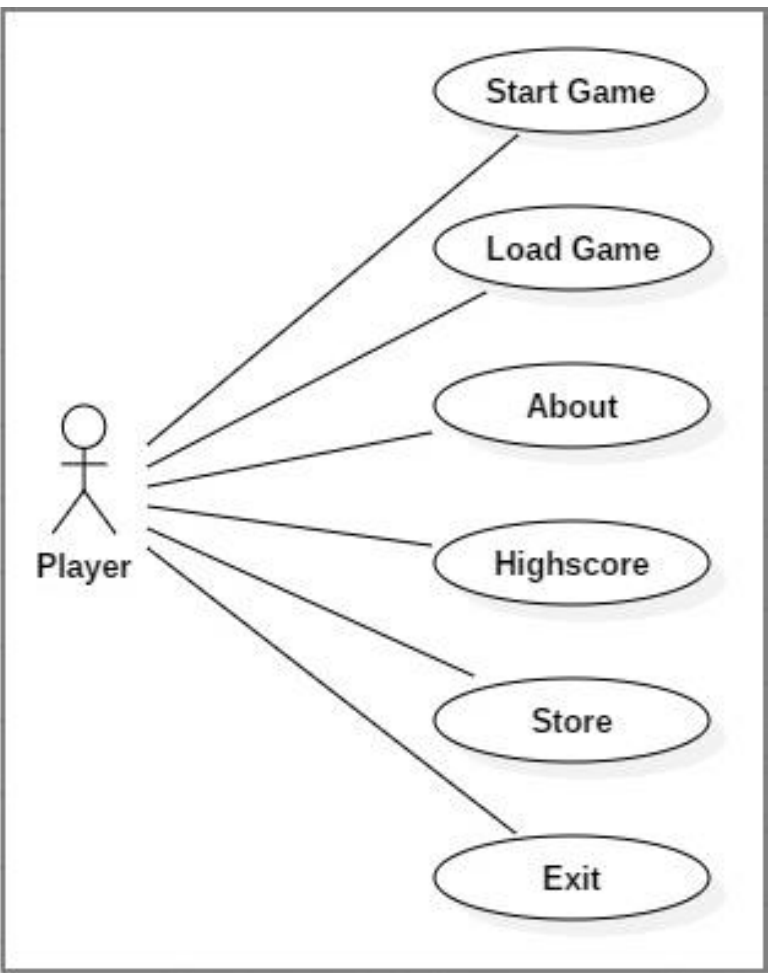

Gambar 2

Use case diagram Augmented Reality Shooting Game

Sistem aplikasi perangkat lunak yang dirancang memiliki enam fungsi utama (key behaviour) yaitu start game, load game, about, highscore, store, dan exit sehingga menjadi enam use case yang berinteraksi langsung dengan pengguna. 


\subsection{Class Diagram}

Class diagram aplikasi perangkat lunak Augmented Reality Shooting Gamedapat dilihat pada gambar 3 .

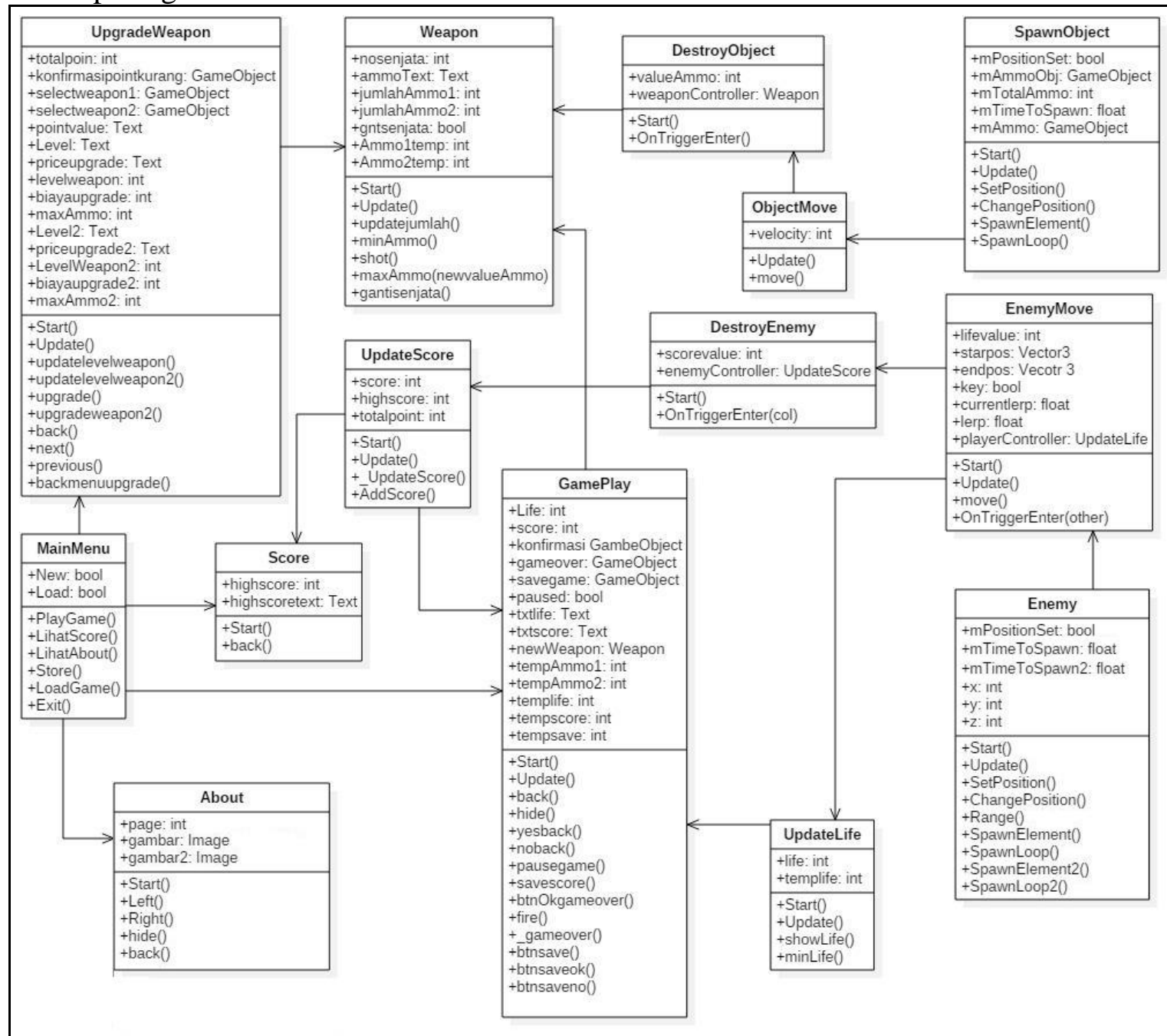

Gambar 3

Class diagram program Shooting Game

\subsection{Activity Diagram}

\subsubsection{Activity DiagramStart Game}

Gambar 4 merupakan aktivitas pada perancangan game Ghost Hunter, dimana user masuk ke aplikasi, lalu sistem akan menampilkan layar menu utama, user menekan tombol start game dan sistem akan mengaktifkan kamera perangkat android. Jika saat sistem mengaktifkan kamera terjadi error, maka sistem akan menampilkan pesan error lalu akan kembali ke menu utama. Apabila tidak terjadi eror maka sistem akan melakukan load enemy dan load senjata, sistem akan masuk ke scene selanjutnya yaitu scene game, dimana user dapat memainkan permainan.

Permainan akan berakhir apabila user menekan button exit, dan kemudian ada dua pilihan jika user menekan "Yes" maka permainan akan berakhir dengan kembali ke menu utama dan score akhir akan disimpan. Jika user menekan "No" maka permainan dilanjutkan kembali. Permainan juga akan berakhir apabila game over atau health user habis, lalu score akan disimpan setelah kita mengisi nama dan menekan button "Yes" selanjutnya sistem akan mengembalikan tampilan ke menu utama. 


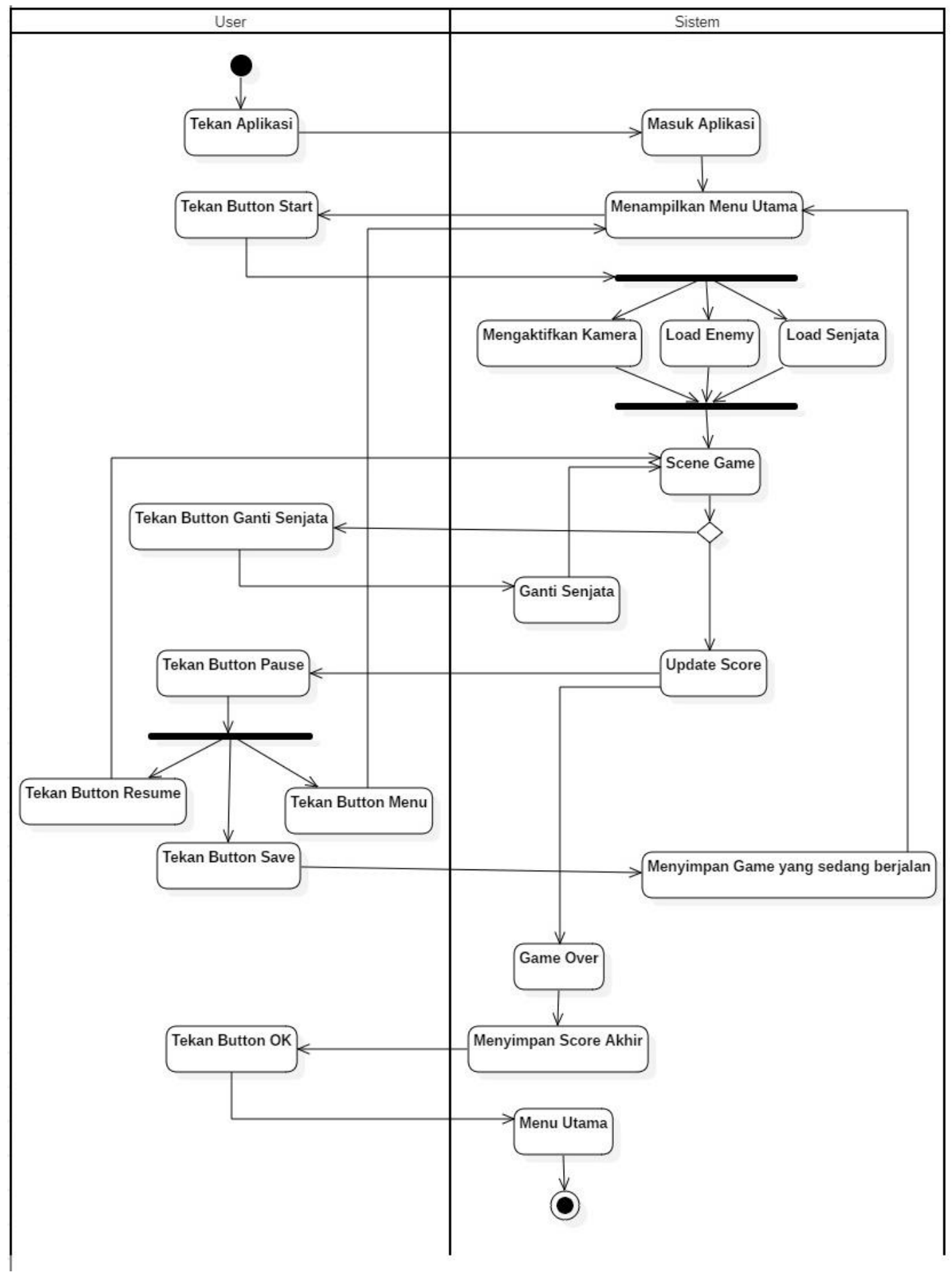

Gambar 4

Activity Diagram Start Game (Swimline)

\subsubsection{Activity DiagramLoad Game}

Gambar 5 merupakan diagram aktivitas untuk menampilkan menuload game, user menekan aplikasi lalu sistem akan masuk ke menu utama, di menu utama user menekan button load game, dimana menu load game akan memuat game yang terakhir kali kita save. 


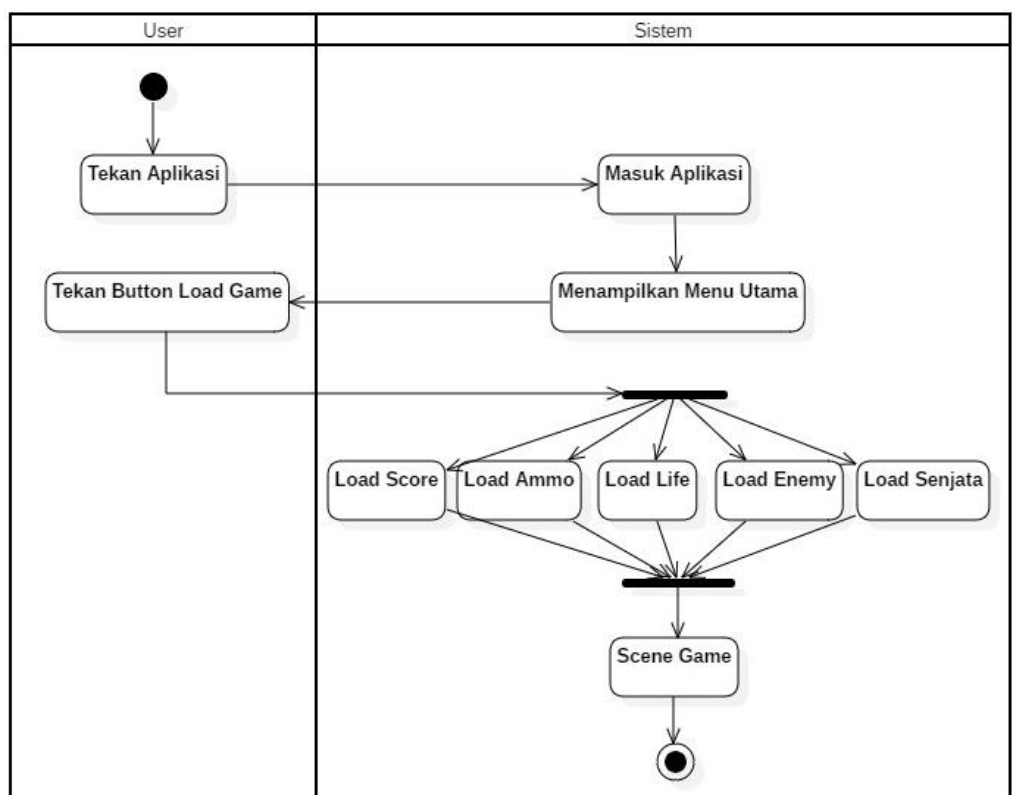

Gambar 5

Activity Diagram Load Game (Swimline)

\subsubsection{Activity DiagramAbout}

Gambar 6 merupakan diagram aktivitas untuk menampilkan menu about, user menekan aplikasi lalu sistem akan masuk ke menu utama, di menu utama user menekan button about, dimana mеnи about akan mendeskripsikan tentang cara memainkan game ini dan juga penjelasan tentang enemy. User dapat menekan button kembali dan sistem akan kembali ke menu utama.

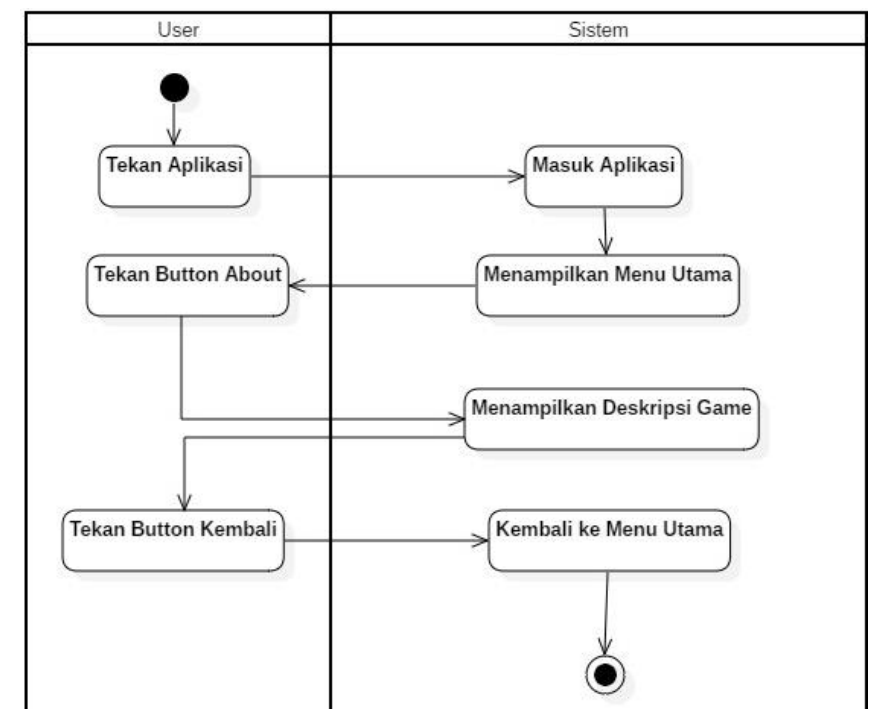

Gambar 6

Activity Diagram About (Swimline)

\subsubsection{Activity DiagramHighScore}

Gambar 7 merupakan diagram aktivitas untuk melihat peringkat score. User menekan aplikasi lalu sistem akan masuk ke menu utama. Di menu utama user dapat melihat peringkat score dengan cara menekan button high score, sistem akan pindah ke tampilan score dan menampilkan peringkat score. Ketika user selesai memainkan game, 
maka score akan disimpan, dan di menu inilah user dapat melihat high score dari permainan yang telah dimainkannya.

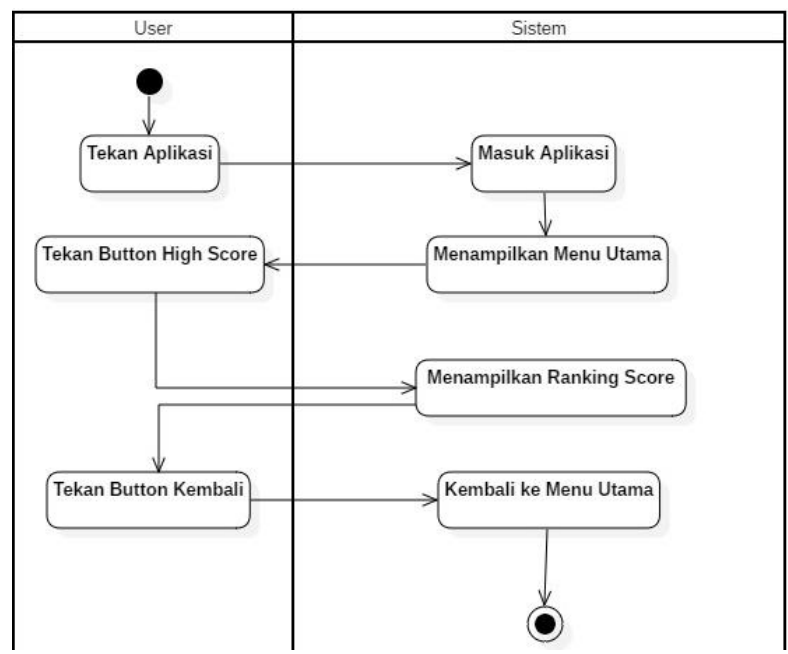

Gambar 7

Activity Diagram High Score (Swimline)

\subsubsection{Activity Diagram Store}

Diagram aktivitas selanjutnya adalah diagram aktivitas untuk melihat atau membeli senjata yang terdapat pada Gambar 8. User menekan aplikasi lalu sistem akan masuk ke menu utama. Di menu utama user dapat menekan button storeuntuk mengupgrade senjata, apabila senjata berhasil diupgrade maka sistem akan update senjata.

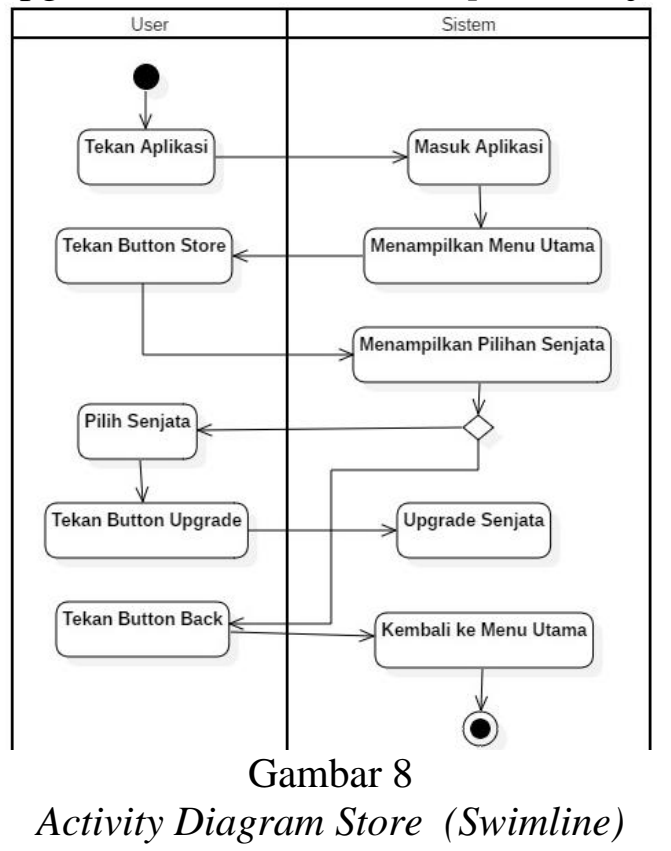

\subsubsection{Activity Diagram Exit}

Diagram aktivitas selanjutnya adalah diagram aktivitas untuk keluar dari aplikasi. Untuk keluar dari aplikasi kita hanya perlu menekan button exit yang ada pada menu utama. Lalu akan muncul form validasi, apabila user memilih ya maka aplikasi akan ditutup. 


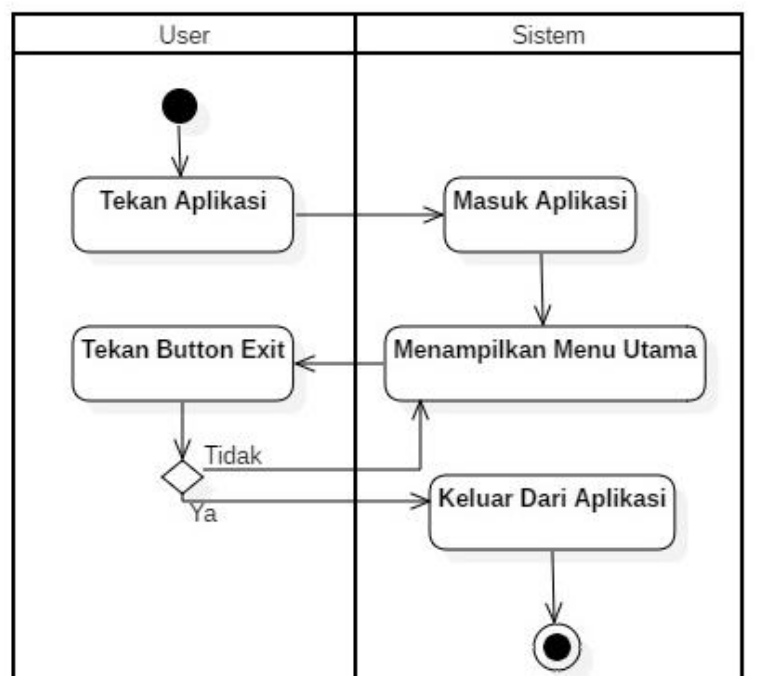

Gambar 9

Activity Diagram Exit (Swimline)

\section{IMPLEMENTASI DAN PENGUJIAN PERANGKAT LUNAK}

\subsection{Spesifikasi Kebutuhan Perangkat Keras}

Spesifikasi perangkat lunak yang digunakan penulis untuk melakukan perancangan dan pengujian perangkat lunak program tertera pada tabel 1 .

Tabel 1

Spesifikasi kebutuhan perangkat keras

\begin{tabular}{|l|l|}
\hline \multicolumn{1}{|c|}{ Perangkat Keras } & \multicolumn{1}{c|}{ Spesifikasi } \\
\hline RAM & Minimum2 GB \\
\hline Memory & 1 GB \\
\hline Camera & Minimum3 MP \\
\hline Sistem Operasi & Android \\
\hline Android Version & Nougat (7.0) \\
\hline RAM & Minimum2 GB \\
\hline
\end{tabular}

\subsection{Pengujian Tampilan Antar Muka}

Berikut ini adalah tampilan antar muka dalam game :

1. Tampilan Menu Utama

Gambar 10 merupakan tampilan menu utama, dimana pemain dapat memilih berbagai menu yang tersedia seperti menu play game untuk memulai permainan, menu load game untuk melanjutkan permainan, dan menu exit untuk keluar dari game, menu about untuk melihat deskripsi singkat tentang game ini, menu score untuk melihat score tertinggi yang telah didapatkan, menu store untuk upgrade level senjata. 


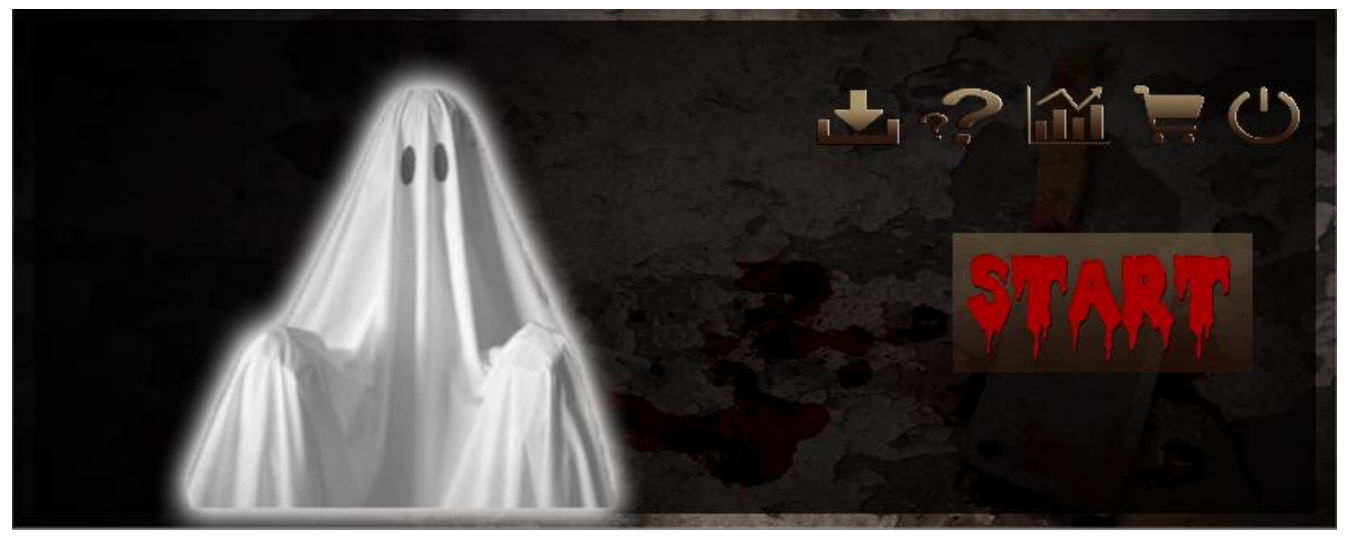

Gambar 10

Tampilan Menu Utama

2. Tampilan Game Play

Gambar 11 merupakan tampilan game play dimana pemain dapat memulai memainkan permainan dengan mengarahkan kamera terhadap objek-objek yang terlihat, lalu menekan button fire untuk menembak. Setiap objek virus yang tertembak akan menambah jumlah score sebesar 10 point, dan juga terdapat jumlah amunisi yang akan berkurang setiap kali pemain melakukan tembakan, setiap score yang didapat akan di akumulasi dan akumulasi score tersebut akan menjadi point yang berfungsi untuk melakukan upgrade senjata.

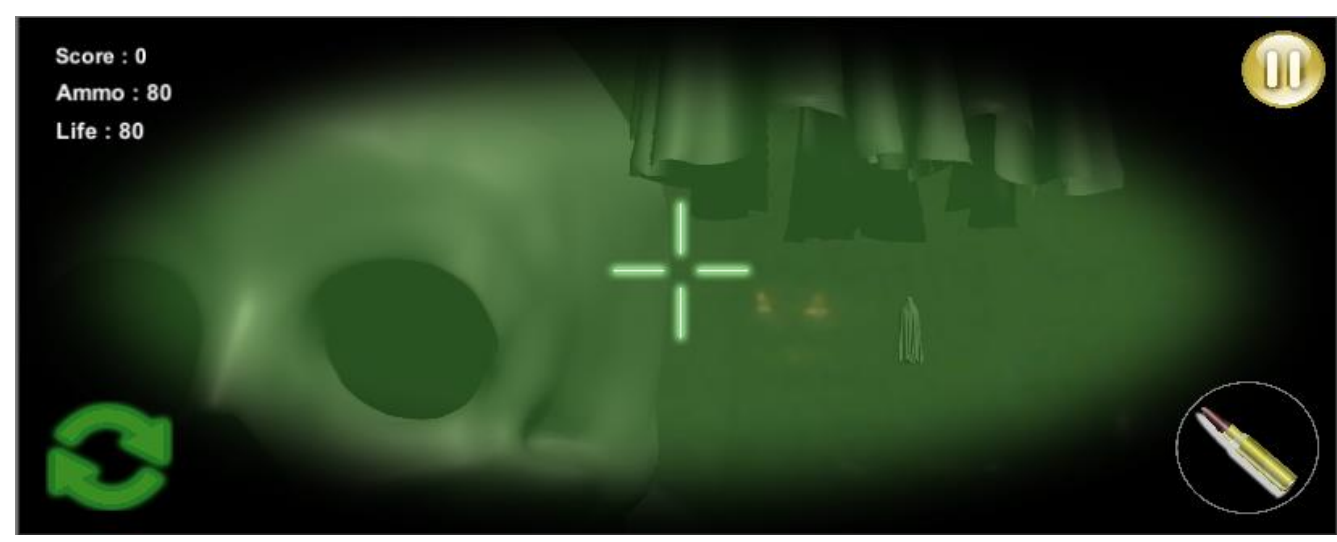

\section{Gambar 11}

Tampilan Game Play

\section{Tampilan Pause}

Gambar 12 merupakan tampilan apabila kita menekan tombol pause saat game play. Maka akan muncul tiga pilihan yaitu resume untuk melanjutkan game, save untuk menyimpan game untuk dilanjutkan kembali nantinya, dan terakhir back to menu untuk keluar dari permainan tanpa di save. 


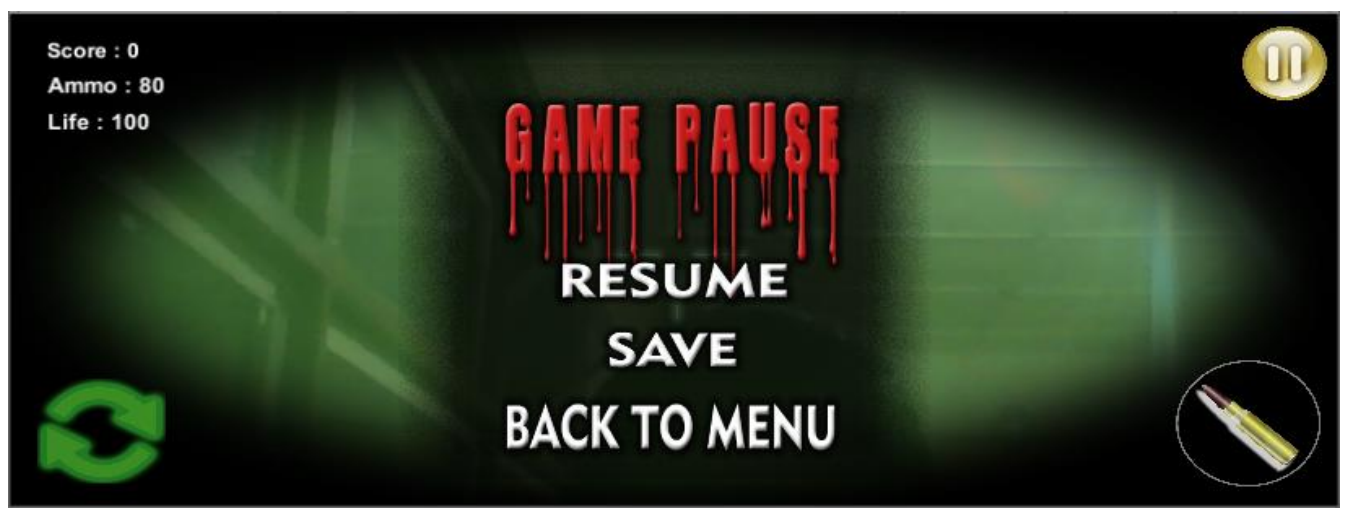

Gambar 12

Tampilan Menu Pause

4. Tampilan Game Over

Gambar 13 merupakan tampilan game over yang muncul apabila nyawa pemain habis atau menunjukkan angka nol, dan pemain pun tidak dapat melanjutkan kembali permainan.

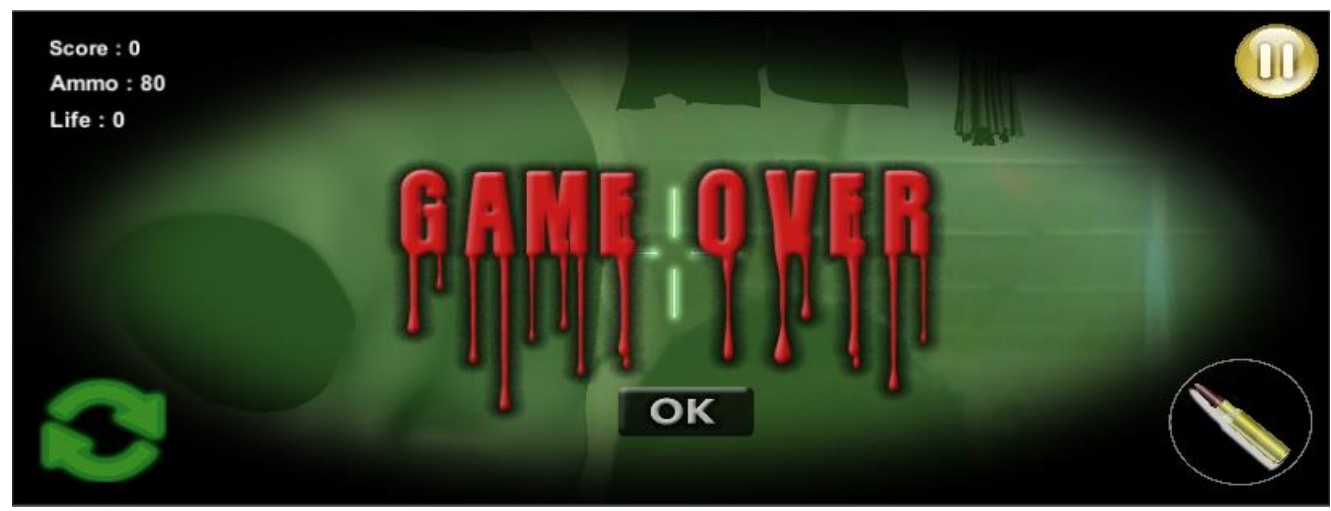

Gambar 13

Tampilan Game Over

5. Tampilan Menu About

Gambar14 merupakan tampilan untuk menu about. Dalam menu ini terdapat penjelasan di setiap halamannya dimana pada halaman pertama akan menampilkan deskripsi singkat tentang cara bermain permainan ini, lalu pada halaman berikutnya terdapat deskripsi singkat tentang musuh yang harus kita hancurkan.

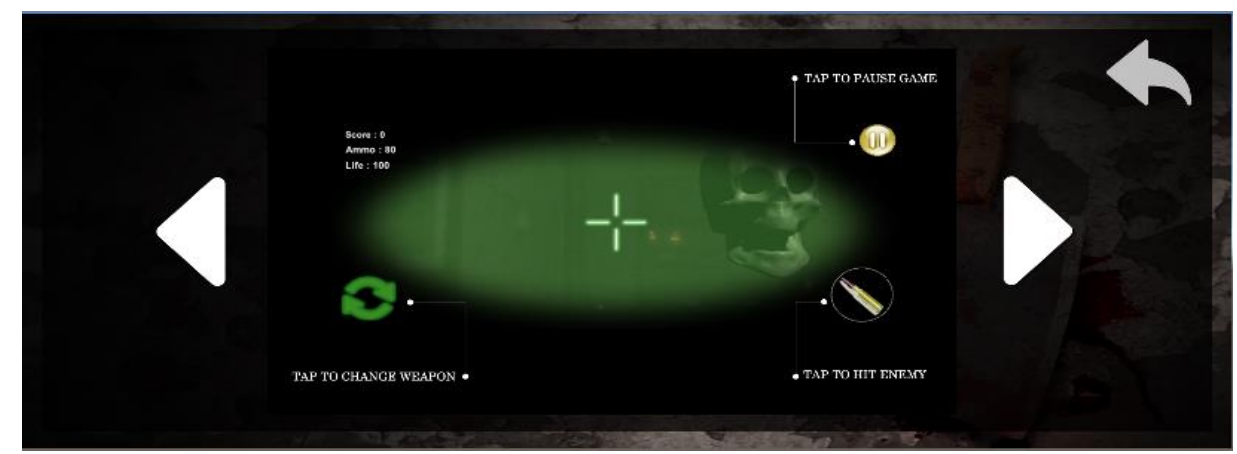

Gambar 14

Tampilan Menu About 
6. Tampilan Menu Highscore

Gambar 15 merupakan tampilan pada menu Highscore, dimana score dari setiap permainan dengan nilai tertinggi akan disimpan dan akan ditampilkan pada menu Highscore.

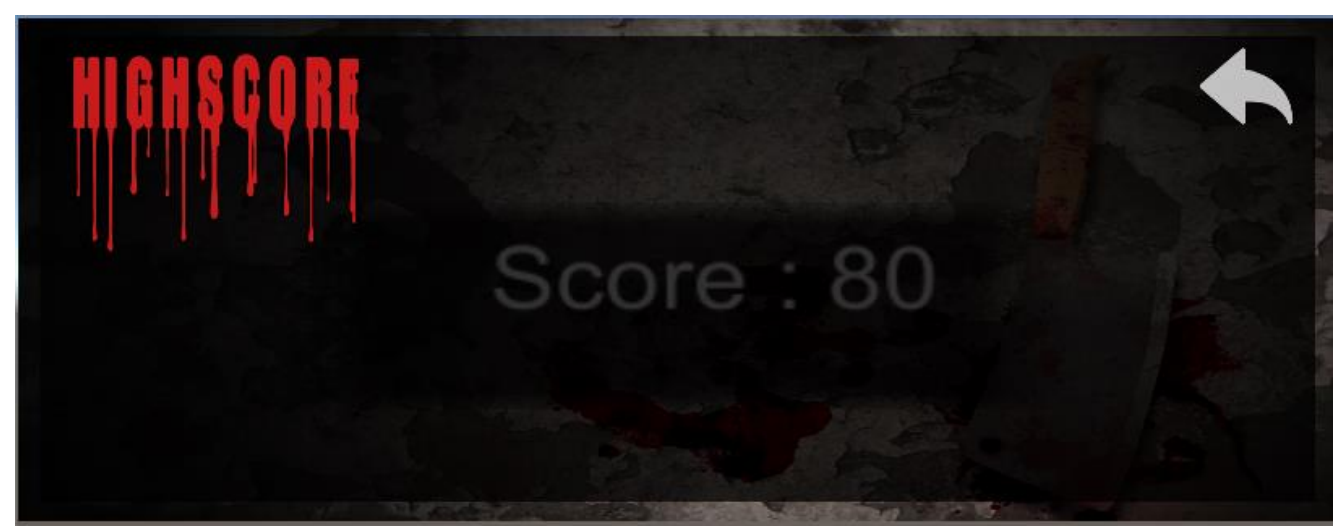

Gambar 15

Tampilan Menu Highscore

7. Tampilan Menu Store

Gambar 16 adalah tampilan menu store yang menampilkan beberapa senjata yang dapat di upgrade ke level yang lebih tinggi. Terdapat point yang dapat digunakan untuk upgrade senjata. Point diperoleh dari setiap score permainan yang dimainkan.

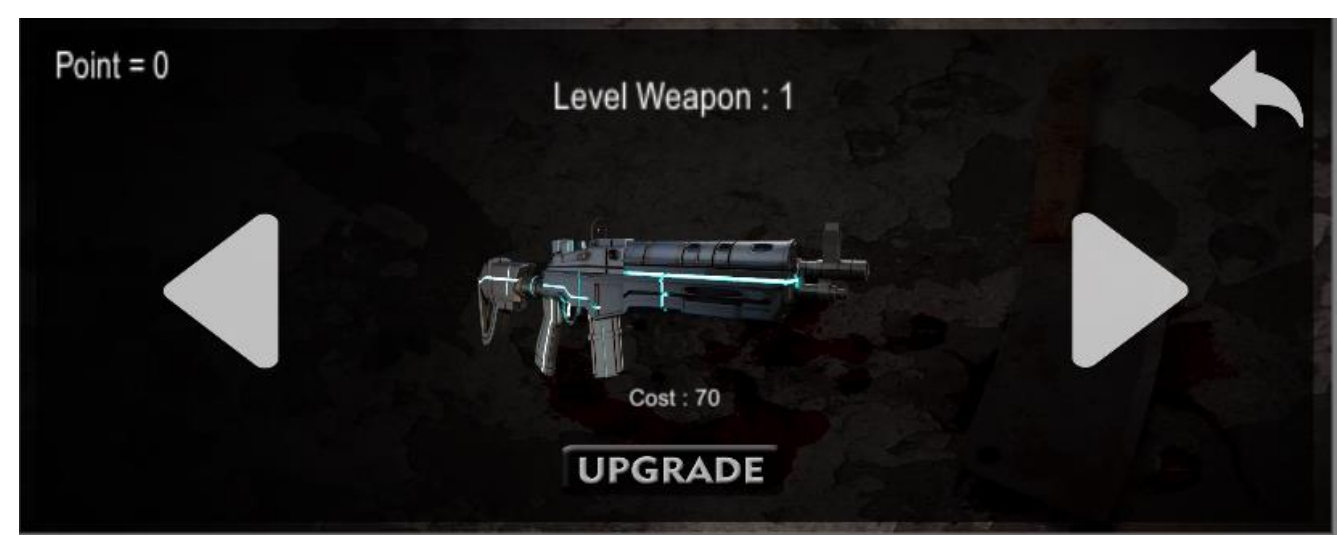

Gambar 16

Tampilan Menu Store

\subsection{Pengujian Fungsi Perangkat Lunak}

Pengujian perangkat lunak dilakukan dengan menggunakan metode black box, sehingga pengujian fungsi-fungsi perangkat lunak menjadi fokus utama. Pengujian dilakukan dengan maksud untuk melihat apakah fungsi-fungsi perangkat lunak sudah berjalan dengan yang diharapkan atau belum.

Tabel 2

Pengujian Tombol-tombol Pada Menu Utama

\begin{tabular}{|l|l|l|l|l|}
\hline No & \multicolumn{1}{|c|}{ Aksi } & \multicolumn{1}{|c|}{$\begin{array}{c}\text { Hasil yang } \\
\text { diharapkan }\end{array}$} & \multicolumn{1}{c|}{ Output } & Keterangan \\
\hline 1 & $\begin{array}{l}\text { KlikButton } \\
\text { Start Game }\end{array}$ & $\begin{array}{l}\text { Menampilkan Scene } \\
\text { Game Play }\end{array}$ & $\begin{array}{l}\text { Menampilkan Scene } \\
\text { Game Play }\end{array}$ & Berhasil \\
\hline
\end{tabular}




\begin{tabular}{|l|l|l|l|l|}
\hline No & \multicolumn{1}{|c|}{ Aksi } & \multicolumn{1}{|c|}{$\begin{array}{c}\text { Hasil yang } \\
\text { diharapkan }\end{array}$} & Output & Keterangan \\
\hline 2 & $\begin{array}{l}\text { Klik Button } \\
\text { Load Game }\end{array}$ & $\begin{array}{l}\text { Menampilkan Scene } \\
\text { Game Play yang sudah } \\
\text { di save }\end{array}$ & $\begin{array}{l}\text { Menampilkan Scene } \\
\text { Game Play yang sudah di } \\
\text { save }\end{array}$ & Berhasil \\
\hline 3 & $\begin{array}{l}\text { Klik Button } \\
\text { About }\end{array}$ & $\begin{array}{l}\text { Menampilkan Scene } \\
\text { About }\end{array}$ & $\begin{array}{l}\text { Menampilkan Scene } \\
\text { About }\end{array}$ & Berhasil \\
\hline 4 & $\begin{array}{l}\text { Klik Button } \\
\text { High score }\end{array}$ & $\begin{array}{l}\text { Menampilkan Scene } \\
\text { High score }\end{array}$ & $\begin{array}{l}\text { Menampilkan Scene } \\
\text { Highscore }\end{array}$ & Berhasil \\
\hline 5 & $\begin{array}{l}\text { Klik Button } \\
\text { Store }\end{array}$ & $\begin{array}{l}\text { Menampilkan Scene } \\
\text { Store }\end{array}$ & $\begin{array}{l}\text { Menampilkan Scene } \\
\text { Store }\end{array}$ & Berhasil \\
\hline 6 & $\begin{array}{l}\text { Klik Button } \\
\text { Exit }\end{array}$ & $\begin{array}{l}\text { Keluar dari aplikasi } \\
\text { Game }\end{array}$ & $\begin{array}{l}\text { Keluar dari aplikasi } \\
\text { Game }\end{array}$ & Berhasil \\
\hline
\end{tabular}

Tabel 3

Pengujian Tombol-tombol Pada Scene Game Play

\begin{tabular}{|c|c|c|c|c|}
\hline No & Aksi & $\begin{array}{c}\text { Hasil yang } \\
\text { diharapkan }\end{array}$ & Output & Keterangan \\
\hline 1 & $\begin{array}{l}\text { Klik Button } \\
\text { Shoot }\end{array}$ & Menembakan peluru & Menembakan peluru & Berhasil \\
\hline 2 & $\begin{array}{l}\text { Klik Button } \\
\text { Change } \\
\text { Weapon }\end{array}$ & Mengganti senjata & Mengganti senjata & Berhasil \\
\hline 3 & $\begin{array}{l}\text { Klik Button } \\
\text { Pause }\end{array}$ & $\begin{array}{l}\text { Menghentikan game } \\
\text { lalu memunculkan } \\
\text { beberapa button }\end{array}$ & $\begin{array}{l}\text { Menghentikan game lalu } \\
\text { memunculkan beberapa } \\
\text { button }\end{array}$ & Berhasil \\
\hline 4 & $\begin{array}{l}\text { Klik Button } \\
\text { Resume }\end{array}$ & $\begin{array}{l}\text { Melanjutkan game } \\
\text { yang sedang di pause }\end{array}$ & $\begin{array}{l}\text { Melanjutkan game yang } \\
\text { sedang di pause }\end{array}$ & Berhasil \\
\hline 5 & $\begin{array}{l}\text { Klik Button } \\
\text { Save }\end{array}$ & $\begin{array}{l}\text { Menyimpan game } \\
\text { yang sedang berjalan } \\
\text { untuk dilanjutkan } \\
\text { kembali nantinya }\end{array}$ & $\begin{array}{l}\text { Menyimpan game yang } \\
\text { sedang berjalan untuk } \\
\text { dilanjutkan kembali } \\
\text { nantinya }\end{array}$ & Berhasil \\
\hline 6 & $\begin{array}{l}\text { Klik Button } \\
\text { Back To } \\
\text { Menu }\end{array}$ & $\begin{array}{l}\text { Kembali ke Scene } \\
\text { Menu Utama }\end{array}$ & $\begin{array}{l}\text { Kembalike Scene Menu } \\
\text { Utama }\end{array}$ & Berhasil \\
\hline
\end{tabular}

Tabel 4

Pengujian Aksi Pada Game Play

\begin{tabular}{|c|l|l|l|l|}
\hline No & \multicolumn{1}{|c|}{ Aksi } & \multicolumn{1}{|c|}{$\begin{array}{c}\text { Hasil yang } \\
\text { diharapkan }\end{array}$} & Output & Keterangan \\
\hline 1 & $\begin{array}{l}\text { Peluru pada } \\
\text { Weapon 1 } \\
\text { mengenai } \\
\text { object } \\
\text { enemy }\end{array}$ & $\begin{array}{l}\text { Enemy hilang dan } \\
\text { score bertambah }\end{array}$ & $\begin{array}{l}\text { Enemy hilang dan score } \\
\text { bertambah }\end{array}$ & Berhasil \\
\hline 2 & $\begin{array}{l}\text { Peluru pada } \\
\text { Weapon 2 } \\
\text { mengenai }\end{array}$ & $\begin{array}{l}\text { Enemy hilang dan } \\
\text { score bertambah }\end{array}$ & $\begin{array}{l}\text { Enemy hilang dan score } \\
\text { bertambah }\end{array}$ & Berhasil \\
\hline
\end{tabular}




\begin{tabular}{|c|c|c|c|c|}
\hline No & Aksi & $\begin{array}{c}\text { Hasil yang } \\
\text { diharapkan }\end{array}$ & Output & Keterangan \\
\hline & $\begin{array}{l}\text { object } \\
\text { enemy }\end{array}$ & & & \\
\hline 3 & $\begin{array}{l}\text { Peluru pada } \\
\text { Weapon } 1 \\
\text { mengenai } \\
\text { object cube }\end{array}$ & $\begin{array}{l}\text { Object cube hilang } \\
\text { dan peluru weapon } 1 \\
\text { bertambah }\end{array}$ & $\begin{array}{l}\text { Object cube hilang dan } \\
\text { peluru weapon } 1 \\
\text { bertambah }\end{array}$ & Berhasil \\
\hline 4 & $\begin{array}{l}\text { Peluru pada } \\
\text { Weapon } 2 \\
\text { mengenai } \\
\text { object } \text { Cube }\end{array}$ & $\begin{array}{l}\text { Object cube hilang } \\
\text { dan peluru weapon } 2 \\
\text { bertambah }\end{array}$ & $\begin{array}{l}\text { Object cube hilang dan } \\
\text { peluru weapon } 1 \\
\text { bertambah }\end{array}$ & Berhasil \\
\hline 5 & $\begin{array}{l}\text { Enemy } \\
\text { mendekati } \\
\text { layar }\end{array}$ & $\begin{array}{l}\text { Enemy hilang dan life } \\
\text { berkurang }\end{array}$ & $\begin{array}{l}\text { Enemy hilang dan life } \\
\text { berkurang }\end{array}$ & Berhasil \\
\hline
\end{tabular}

Tabel 5

Pengujian Tombol-tombol Pada Menu About

\begin{tabular}{|c|l|l|l|l|}
\hline No & \multicolumn{1}{|c|}{ Aksi } & \multicolumn{1}{|c|}{$\begin{array}{c}\text { Hasil yang } \\
\text { diharapkan }\end{array}$} & \multicolumn{1}{|c|}{ Output } & Keterangan \\
\hline 1 & $\begin{array}{l}\text { Klik Button } \\
\text { Next }\end{array}$ & $\begin{array}{l}\text { Berpindah ke halaman } \\
\text { selanjutnya }\end{array}$ & $\begin{array}{l}\text { Berpindah ke halaman } \\
\text { selanjutnya }\end{array}$ & Berhasil \\
\hline 2 & $\begin{array}{l}\text { Klik Button } \\
\text { Previous }\end{array}$ & $\begin{array}{l}\text { Berpindah ke halaman } \\
\text { sebelumnya }\end{array}$ & $\begin{array}{l}\text { Berpindah ke halaman } \\
\text { sebelumnya }\end{array}$ & Berhasil \\
\hline 3 & $\begin{array}{l}\text { Klik Button } \\
\text { Back }\end{array}$ & $\begin{array}{l}\text { Kembali ke tampilan } \\
\text { menu utama }\end{array}$ & $\begin{array}{l}\text { Kembali ke tampilan } \\
\text { menu utama }\end{array}$ & Berhasil \\
\hline
\end{tabular}

Tabel 6

Pengujian Tombol-tombol Pada Menu Highscore

\begin{tabular}{|c|l|l|l|l|}
\hline No & \multicolumn{1}{|c|}{ Aksi } & \multicolumn{1}{|c|}{$\begin{array}{c}\text { Hasil yang } \\
\text { diharapkan }\end{array}$} & \multicolumn{1}{c|}{ Output } & Keterangan \\
\hline 1 & $\begin{array}{l}\text { Klik Button } \\
\text { Back }\end{array}$ & $\begin{array}{l}\text { Kembali ke tampilan } \\
\text { menu utama }\end{array}$ & $\begin{array}{l}\text { Kembali ke tampilan } \\
\text { menu utama }\end{array}$ & Berhasil \\
\hline
\end{tabular}

Tabel 7

Pengujian Tombol-tombol Pada Menu Store

\begin{tabular}{|c|l|l|l|l|}
\hline No & \multicolumn{1}{|c|}{ Aksi } & \multicolumn{1}{|c|}{$\begin{array}{c}\text { Hasil yang } \\
\text { diharapkan }\end{array}$} & \multicolumn{1}{|c|}{ Output } & Keterangan \\
\hline 1 & $\begin{array}{l}\text { Klik Button } \\
\text { Next }\end{array}$ & $\begin{array}{l}\text { Berpindah ke halaman } \\
\text { senjata selanjutnya }\end{array}$ & $\begin{array}{l}\text { Berpindah ke halaman } \\
\text { senjata selanjutnya }\end{array}$ & Berhasil \\
\hline 2 & $\begin{array}{l}\text { Klik Button } \\
\text { Previous }\end{array}$ & $\begin{array}{l}\text { Berpindah ke halaman } \\
\text { senjata sebelumnya }\end{array}$ & $\begin{array}{l}\text { Berpindah ke halaman } \\
\text { senjata sebelumnya }\end{array}$ & Berhasil \\
\hline 3 & $\begin{array}{l}\text { Klik Button } \\
\text { Upgrade }\end{array}$ & $\begin{array}{l}\text { Level senjata } \\
\text { bertambah dan poin } \\
\text { berkurang }\end{array}$ & $\begin{array}{l}\text { Level senjata bertambah } \\
\text { dan poin berkurang }\end{array}$ & Berhasil \\
\hline 4 & $\begin{array}{l}\text { Klik Button } \\
\text { Back }\end{array}$ & $\begin{array}{l}\text { Kembali ke tampilan } \\
\text { menu utama }\end{array}$ & $\begin{array}{l}\text { Kembali ke tampilan } \\
\text { menu utama }\end{array}$ & Berhasil \\
\hline
\end{tabular}


Tabel 8

Hasil Pengujian Terhadap Lingkungan

\begin{tabular}{|c|l|l|}
\hline No & \multicolumn{1}{|c|}{ Lingkungan } & \multicolumn{1}{c|}{ Hasil } \\
\hline 1 & Lingkungan dengan pencahayaanterang & Semua animasi / objek muncul \\
\hline 2 & Lingkungan dengan pencahayaan redup & Semua animasi / objek muncul \\
\hline 3 & Lingkungan dengan pencahayaan gelap & Semua animasi / objek muncul \\
\hline
\end{tabular}

Tabel 9

Hasil pengujian pada Smartphone

\begin{tabular}{|c|l|l|}
\hline No & \multicolumn{1}{|c|}{ Tipe Smartphone } & \multicolumn{1}{c|}{ Hasil } \\
\hline 1 & Xiaomi Redmi 5 Plus & $\begin{array}{l}\text { Semua animasi / objek muncul, dan game bisa } \\
\text { dimainkan dengan baik. }\end{array}$ \\
\hline 2 & Asus Zenfon Max Pro M1 & $\begin{array}{l}\text { Semua animasi / objek muncul, dan game bisa } \\
\text { dimainkan dengan baik. }\end{array}$ \\
\hline 3 & Iphone 8+ & File game tidak terbaca. \\
\hline
\end{tabular}

Hasil dari pengujian fungsi dengan menggunakan metode black box telah dilakukan dan dapat dilihat pada tabel-tabel diatas, dimana program yang dibuat sudah berjalan dengan sebagaimana mestinya. Pembuatan shooting game dengan menggunakan augmented reality dengan sistem operasi android dapat dilakukan dan berjalan dengan baik menggunakan game engine Unity.

Lingkungan pencahayaan pun tidak menjadi masalah dikarenakan aplikasi "Ghost Hunter" tidak membutuhkan marker untuk dilacak oleh kamera. Metode yang digunakan adalah device trackingyang merupakan salah satu dari berbagai jenis markerless, sehingga animasi / objek akan tetap muncul dengan kondisi pencahayaan yang tidak menentu

\section{KESIMPULAN}

Kesimpulan dari rekayasa perangkat lunak perancangandan pembuatan augmented realityshooting game yaitu Pembuatan gamedengan tipe shooting game dipadukan dengan Augmented Reality yang diaplikasikan pada platform android, dapat dibuat menggunakan game engine Unity3D dengan bantuan dari Software Development Kit Vuforia.

\section{DAFTAR PUSTAKA}

Clark, Dan, 2013, Begining C\# Object-Oriented Programming, New York : Apress.

Craig, B, A., 2013,Understanding Augmented Reality : Concept and Application, United State : Morgan Kaupmann.

Creighton, Henson Ryan., 2011, United 3D Game Development by Example Beginner Guide : Lite, Birmingham : PACKT.

Dregvite, Giedre., Robertas, Damasevicius, 2016, Information and Software Technology, Switzerland : Springer International.

Enterprise, Jubilee, 2010, TrikBermain Game Android di PC, Elex Media Komputindo.

Fernando, Mario, 2013, MembuatAplikasi Android Augmented Reality Menggunakan Vuforia SDK dan Unity, Solo : Buku AR Online.

Fishwick. A. P, 2008, Aesthetic Computing, London : The MIT Press.

Flavell, Lance, 2017, Beginning Blender, Apress.

Furht, Borko, 2011, Handbook of Augmented Reality, Florida : Spinger. 
Harwani, B, M., 2012, Android Programming Unleashed, United State : Pearson Education, Inc.

Kipper, Gred., Rampolla, Joseph, 2012, Audgented Reality : An Emerging Technologies Guide to AR, USA : Elevier, Inc.

Lethbrige, C, Timothy. Laganiere, Robert , 2011, Object-Oriented Software Engineering, McGrawHill.

Nugroho, Adi, 2009, Rekayasa Perangkat Lunak menggunakan UML dan JAVA, C.V ANDI OFFSET.

Nugroho, Adi, 2010, Rekayasa Perangkat Lunak Berorientasi Objek dengan Metode USDP, C.V ANDI OFFSET.

Pramudya, Puja, 2011, Membuat Aplikasi Mobile dengan Qt SDK, Yogyakarta : Andi.

Pressman, Roger S, 2010, Software Engineering : A Pradictioner's Approach Seventh Edition, New York : McGraw-Hill Companies, Inc.

Rafrastara, A. F, dkk, 2009, Membuat Game Fighting dengan Flash, Jakarta : PT Elex Media Komputindo.

Roedavan, Rickman, 2014, Unity Tutorial Game Engine, INFORMATIKA.

Siberto, Ivan C, 2009, Langkah Membuat Game 3D, Yogyakarta : MediaKom.

Simarmata, Janner, 2010, Rekayasa Perangkat Lunak, C.V. ANDI OFFSET.

Sommerville, Ian, 2011, Software Engineering 9th Edition, Cloth.

Thron, Alan, 2013, Unity 4 Fundamentals : Get Started at Making Games with Unity, United Kingdom : Focal Press.

Vandome, Nick, 2014, Android Tablet in Easy Steps : Fully Illustrated Using Google Nexus, United Kingdom : In Easy Steps Limited.

Vento, Mario, 2009, Image Analysis and Processing - ICIAP 2009, Vietri sul Mare : Springer. 